\section{Monofilament Lines Fail to Protect Grapes from Bird Damage}

\author{
Donald H. Steinegger', Danilo A. Agüero' ${ }^{2}$, Ron J. Johnson ${ }^{3}$, and \\ Kent M. Eskridge ${ }^{4}$ \\ Department of Horticulture, University of Nebraska, Lincoln, NE 68583
}

Additional index words. house sparrow (Passer domesticus), European starling (Sturnus vulgar-is), American robin (Turdus migratorius), northern oriole (Icterus galbula), Vitis

Birds feeding on horticultural crops may cause extensive losses, but control techniques currently available are not always practical or otherwise appropriate. Control of certain birds is attempted by placing widely spaced lines or wires over or around sites needing protection (Pochop et al., 1990). Recently, Knight (1988) reported observations that monofilament lines could be used to protect various horticultural crops, including grapes, from bird damage. However, more closely controlled research was needed to better quantify effectiveness of this technique for various bird species. The objectives of this study were to determine the effectiveness of monofilament lines in protecting ripening grapes (Vitis) from bird damage and to observe how damage-causing bird species behave in relation to the lines.

We selected the vineyard at the Univ. of Nebraska horticultural garden because of its availability and its history of bird damage ranging from $30 \%$ to $100 \%$ of the crop (D.H.S., unpublished). The study was conducted from 17 July through 25 Sept. 1988, and included seven grape cultivars, each with four or more plants (Table 1). Plants of the various cultivars were distributed haphazardly throughout the vineyard. Each grape bunch on all plants was tagged and visually examined before ripening occurred. Plants were individually and randomly assigned to control (no lines) or experimental groups. Each experimental plant received, sepa-

Received for publication 24 Aug. 1990. Journal Series no. 9294, Agricultural Research Div., Univ. of Nebraska. We thank J.M. Knight for advice and ideas during the design of this project and M.M. Beck, R.M. Case, W.A. Gustafson, and E.T. Paparozzi for manuscript reviews. The cost of publishing this paper was defrayed in part by the payment of page charges. Under postal regulations, this paper therefore must be hereby marked advertisement solely to indicate this fact.

'Professor of Horticulture.

'Graduate Student, Dept. of Forestry, Fisheries, and Wildlife. Current address: Estacion Experimental Portuguese, Apartado 102, Acarigua, Estado Portuguese, Venezuela.

Associate Professor, Dept. of Forestry, Fisheries, and Wildlife.

${ }^{4}$ Assistant Professor, Dept. of Biometry. lines spaced $30 \mathrm{~cm}$ apart. lines, using independent two-sample $t$ tests.

'No. of plants in parentheses. rately, clear $5.4-\mathrm{kg}$ test monofilament lines spaced $30 \mathrm{~cm}$ apart, attached horizontally and parallel between two rigid $100-\mathrm{cm}$-diameter wire hoops. The wire hoops were supported by the poles of the grape trellis. Grapes were considered to be damaged if they were either pecked or missing (Boudreau, 1972). The percentage of grapes damaged in each grape bunch was estimated every 4 to 5 days throughout the susceptible ripening period (Hothem et al., 1981) and individual bunch ratings were averaged for each plant. Cultivars were analyzed separately for treatment effects because the cultivars were known to differ with regard to fruit ripening time.

Bird damage reached $100 \%$ in all grape cultivars regardless of presence of lines, and damage within cultivars occurred at similar rates with or without lines. The mean number of days for damage to reach $100 \%$ in all plants within cultivars ranged from $12 \pm 2.1$ ('Leon Millet') to $54 \pm 7.5$ ('Bath'). Comparisons between control and experimental plants for each cultivar, using an independent two-sample $t$ test, showed no difference in the mean number of days to $50 \%$ damage (Table 1). European starlings (Sturnus vulgaris), American robins (Turdus migratorious), northern orioles (Icterus galbula), and three other incidental species were observed going through the lines into plants. For example, European starlings were observed passing through the lines 32 times, 24 by flying and eight by hopping from the hoop or support pole. Most of the bird species entering through lines were flying or, to a lesser extent, hopping from a perch or the ground. Regardless of lines, damage occurred more slowly in some cultivars than others and was slowest in 'Bath' and 'McCampbell' grapes. 'Leon Millet' apparently was the most vulnerable to bird damage, a result possibly related to the cultivar (small, dark, sweet grapes) and the feeding habits of the bird species present, which typically damage grapes by plucking (Boudreau, 1972).

Our results differ from Knight's (1988) observations that lines would protect grapes from bird damage. However, house sparrows (Passer domestics), the species most noted by Knight (personal communication), were not present in this study. Subsequent studies at baited sites, which included various combinations of line size, color, orientation, and spacing, have confirmed that monofilament lines effectively repel house sparrows from certain feeding sites but do not repel European starlings (Agüero, 1990). Why lines repel only certain birds is not fully understood (Pochop et al., 1990). In this study, American robins, European starlings, and northern orioles appeared to be undeterred by lines around grape plants, and grape damage was total. Further studies are needed to better understand bird response to lines and potential management implications.

\section{Literature Cited}

Agüero, D.A. 1990. Evaluation of monofilament lines to prevent damage by birds. MS Thesis, Univ. of Nebraska, Lincoln.

Boudreau, G.W. 1972. Factors related to bird depredations in vineyards. Amer. J. Enol. Viticult. 23:50-53.

Hothem, R.L., D.F. Mott, R.W. DeHaven, and J.L. Guarino. 1981. Mesurol as a bird repellent on wine grapes in Oregon and California. Amer. J. Enol. Viticult. 32:150-154.

Knight, J.E. 1988. Preventing bird depredations using monofilament line. Coop. Extension Guide L-206, New Mexico State Univ., Las Cruces, NM.

Pochop, P.A., R.J. Johnson, D.A. Agüero, and K.M. Eskridge. 1990. The status of lines in bird damage control-a review. Proc. Vertebr. Pest Conf. 14:317-324

Table 1. Mean number of days to $50 \%$ fruit damage by birds in grapes with or without monofilament

\begin{tabular}{lccc}
\hline \hline Grape cultivar & $\begin{array}{c}\text { Plants } \\
\text { without lines }\end{array}$ & $\begin{array}{c}\text { Plants } \\
\text { with lines }\end{array}$ & Probability \\
\hline Reliance & $13.5(2)^{\mathrm{y}}$ & $12.3(3)$ & 0.66 \\
New York Muscat & $20.5(2)$ & $22.0(3)$ & 0.89 \\
McCampbell & $35.7(3)$ & $31.0(3)$ & 0.51 \\
Bath & $34.8(4)$ & $35.0(4)$ & 0.88 \\
Vine Red & $39.0(3)$ & $31.7(3)$ & 0.32 \\
Fredonia & $32.0(2)$ & $29.0(2)$ & 0.54 \\
Leon Millot & $2.8(4)$ & $6.0(4)$ & 0.14 \\
\hline
\end{tabular}

"Probability of no difference in the mean number of days to $50 \%$ damage in plants with or without 